\title{
A study of speaking in tongues in Acts and 1 Corinthians and its use and abuse in some selected contemporary churches in Nigeria
}

\author{
Michael Oyebowale Oyetade \\ University of Ilorin, Nigeria \\ droyetademich@gmail.com / oyetade.mo@unilorin.edu.ng
}

\begin{abstract}
There are much confusion and controversy in our churches today about the phenomenon known as speaking in tongues. Some claim that the gift of speaking in tongues continues in our time as the Holy Spirit miraculously moves persons to speak in a language they had never learned. Other believers are convinced that the Scriptures leave no room for the continuation of that special gift beyond the founding era of the Apostolic church. To worsen it all pagans abound in such ecstatic utterances and are convinced they are from God. The objective of this paper is to investigate both the use and abuse of speaking in tongues. Historical and exegetical methods were used. Data were gathered through primary and secondary sources. The paper found out that speaking in tongues was miraculously used by God at Pentecost and in the earliest churches in the apostolic era. But there were distinguishing features that marked it out from the psychological phenomenon found among pagans. In our contemporary church in Nigeria, the only way to test the source is by comparison with what God explains in his word about the purpose and occasion for the legitimate manifestation.
\end{abstract}

Keywords

Church; Nigeria; tongues; Pentecostals; abuse; use

\section{Introduction}

In the words of Ojo (2018:77), there is no doubt that Pentecostalism has awakened in Nigerians an eagerness for spiritual life in the secular world, and a desire for an experiential communion with God in prayers. People are now giving serious attention to their prayer life. There is a noticeable guest for a spirituality based on a personal relationship with the Lord, which for instance in the Catholic Church is manifested in love for private Eucharistic adoration. 
Pentecostalism, according to Achunike (2004:95-96), is noted for encouraging a spirituality that abhors confinement and standardization, while provoking an intimate experience of the Holy Spirit.

Many Nigerians are now after a spirituality that is manifested in power since seeing is believing. The power is proof of the validity and authenticity of the religious life of an individual. In this context, Achunike observes that: "People are looking for men of God and Spiritual masters and the results their encounter with these men of God will yield for them." To this end, religious pragmatism is becoming a feature of spirituality and prayer in Nigeria (Achunike 2004:99).

Pentecostalism is a religious phenomenon that emphasizes the presence and activities of the Holy Spirit in more dynamic ways in the lives of Christians, and which also insists that baptism of the Holy Spirit is a second experience after the conversion experience; indeed, the Pentecostals identify the Pentecostal experience as the most identifiable mark of a Christian. The Holy Spirit baptism, according to O’Donovan (1996:128), has the power to change people's character and behaviour, and to help them become more and more like Christ since that is a supernatural act of God which makes us part of the church. As a result, the church can effectively oppose the evil work of demons through her prayers and by using the weapons of spiritual warfare. The Charismatic Renewal is usually associated with the belief that there is another important experience after the conversion experience called the baptism of the Holy Spirit, which is believed to impact a dynamic spirituality in the lives of believers. Indeed, there are pieces of evidences and testimonies to affirm this fact. The events in Acts 2 and similar passages in chapters 10 and 19 form the basis of the experience of the baptism of the Holy Spirit. Allan Anderson has remarked on the primacy of religious experience associated with the Holy Spirit and charismatic gifts as the foundation for Pentecostal spirituality through the ages (Anderson 2004:19,38).

Unger (1984:440) calls speaking in tongues, or glossolalia (from the Greek glôssais lalô) in Acts 2:4, supernatural tongues or the sign of tongues. This supernatural tongue is a means by which the Holy Spirit witnessed to Israel on the day of Pentecost $(2: 4-13 ; 10: 45,47 ; 19: 6)$. They were a sign of the truth that Jesus was the Messiah and an indication of the new age of the spirit 
in which Christians speak in a language they have never learned (Acts 2:4; 1Cor 14:14-15). It may be in existing spoken human languages (Acts 2:6) or in languages unknown on earth (cf. 1Cor 13:1) which is still valid for us today. It is not "ecstatic speech," as rendered in some translations, for the Bible never uses the term "ecstatic utterance" to refer to "speaking in tongues".

According to Klaude (1961:53):

Although Agnes Ozman was not the first person in modern times to speak in "tongues", she was the first person to have received such an experience as a result of specifically seeking baptism in the Holy Spirit with the expectation of speaking in tongues. From this time Pentecostal believers were to teach that the baptism in the Holy Spirit should be sought and that it would be received with the evidence of 'tongues.' For this reason, the experience of Agnes Ozman is designated as the beginning of the Modern Pentecostal Revival.

Zimmerman (1963:319) writes that while some divergence of doctrine exists, one basic position unites Pentecostals of their common belief that "the baptism of the Holy Spirit" is a distinct experience which all believers may and should have after conversion. Farrell (1963:1163) also adds that Common to all Pentecostals is the one basic belief that "the baptism of the Holy Spirit" is experience after conversion - all believers should have it, and the initial physical evidence for this baptism or infilling is the speaking of tongues.

However down through the years, the most controversial gift has been tongues. It was controversial on the day of Pentecost in Jerusalem; it was controversial a few years later in Caesarea; it was controversial later on in Corinth. The issue of tongues has divided the evangelical community, becoming symbolic, if not definitive, and the difference between "charismatic and non-charismatic" churches.

Ojo (2018:79) opines that both Pentecostals and Charismatics believe in the Pentecostal doctrines of the baptism of the Holy Spirit and speaking in tongues. However, Charismatics are trans-denominational and more ecumenical in their Pentecostal expression than the Pentecostals, who often 
come from the classical Pentecostal denominations such as Apostolic Faith Mission, Assemblies of God, Foursquare Gospel Church, The Apostolic Church, Elim Gospel Church, etc. Charismatic renewal in the 1960s and early 1970s carried with it no desire to form an independent fellowship as the Pentecostal assemblies did in the early decades of the twentieth century.

Yet, no biblical topic has received more scrutiny than "glossolalia", speaking in tongues which have attracted a variety of explanatory propositions from theologians of all persuasions, that is, scholars and scientists from nearly all academic disciplines (Cartledge 2006:21). To most Pentecostals like The Redeemed Christian Church of God, The Assemblies of God Church among others as well as some Indigenous churches like Christ Apostolic Church and The Apostolic Church, the gift of tongues is both a strong tenet and a "litmus test" for spirit-baptism. They also insist that their ministers must be tongue-speakers (Menzies 1998:175).

Today, millions of Christians are found in the neo-Roman Catholic churches that are the charismatic ones, some in liberal mainstream groups, some in conservative evangelical churches, and many in Pentecostal denominations, speak in tongues. That is, they speak supernatural tongues which are apparently in languages unknown to the speaker, this is different from multilingualism which is the ability of an individual speaker or a community of speakers to communicate effectively in three or more languages (Procter 1981:717). Even though tongues-speaking has such diverse participants, it is still controversial. Pattison further adds that everybody in religious circles these days seems to be talking about tongues, if not in tongues. So-called tongues-speaking, or glossolalia, is variously said to be psychotic babbling, neurotic fakery, or the deception of the devil, on the one hand; or claimed on the other hand as a necessary experience for all Christians before they can consider themselves wholly sanctified (Pattison 1964:99).

One of the chief causes of controversy is the failure to distinguish between the different kinds of tongues, which are manifested through the Spiritfilled believers. Many people do not realize there is a difference between tongues as the initial evidence of being filled with the Holy Spirit, devotional tongues, and the manifestation of tongues, in a congregation of believers. When this distinction is not made between these three kinds 
of tongues, much confusion can result. Again, most Pentecostals, however, admit that the events recorded in Acts 10 and 19 are not identical to the situation at Corinth, as described in I Corinthians 12-14. They distinguish between speaking in tongues as a sign of this Spirit, baptism and speaking in tongues as a permanent gift (1 Cor 13:9-13). Donald Gee (1961:91), one of the recognized leaders of the worldwide Pentecostal movement, declares: "The two subjects are distinct, and should never be confused." It is therefore incorrect, even from the Pentecostal point of view, to demand that all believers have the permanent gift of tongues. The permanent gift is only granted to some believers, as Paul indicates in I Corinthians 12:30. At the same time, however, they maintain that every believer should at least once in his life speak in tongues when he receives the baptism by the Spirit. In light of these controversies, the author considers it necessary to investigate both the use and abuse of this phenomenon that is dividing the church.

\section{Conceptualization of tongues}

Tongues ( $g l o \overline{s s} a \gamma \lambda \tilde{\omega} \sigma \sigma \alpha)$ is a feminine noun in the dative case and a plural form. It is used in the New Testament writings fifty times. It means in the literal sense tongues as a bodily organ and especially as the organ of speech. The chief theological emphasis lies in Acts and 1 Corinthians 12 and 14; the tongues of fire that rested on the disciples (Acts 2:1-4) are a picture of the baptism with the fire of the Holy Spirit, and the speaking "in other tongues" is a sign of the working of the spirit (1 Cor 12:10, 28) (Verbrugge 2000:110). The word "tongues" translated from the Greek, simply means "languages". Does this mean that the language is a known language with vocabulary, syntax, and grammar? To some, the tongues are a foreign language. To others, the tongues are a heavenly language (and not at all like any language spoken by men somewhere on this earth (Dalton 1945:19). Horton, (2007:145) has this explanation of the nature of tongues: It is a supernatural utterance by the Holy Spirit in languages never learned by the speaker - not understood by the mind of the speaker - nearly always not understood by the hearer. It has nothing to do with linguistic ability, nor with the mind or intellect of man. It is a manifestation of the mind of the Spirit of God employing human speech organs. When a man is speaking with tongues his mind, intellect, understanding is quiescent. It is 
the faculty of God that is active. Man's will, certainly, is active, and his spirit and his speech organs; but the mind that is operating in the mind of God through the Holy Spirit. The linguistic skill of man is no more employed in speaking with tongues than the surgical skill of man was employed when at Peter's word, "Rise and walk," the lame man instantly arose and leaped and walked! It is in short, a miracle. It is not a mental miracle; the mentality is God's. It is a vocal miracle. Both Zimmerman (1963:12) and Brumback (1947:89) refer to scattered instances throughout church history as evidence of the truth that speaking in tongues has continued all through the church age. It is affirmed that all the spiritual gifts have continued through the centuries.

According to Ojo (2018:79), there have been several claims of the influence of the Holy Spirit in the lives of Christians in Africa. In Nigeria, there were instances of Christians in the Anglican Church in the first decade of the twentieth century who emphasized the work of the Holy Spirit in local revival groups. One of such was led by Garrick Sokari Braide, a prophet, and evangelist in the Bonny area of the Niger Delta. Likewise, Moses Orimolade and the other pioneer prophets of the Aladura churches in Western Nigeria equally paid attention to the work of the Holy Spirit. The Aladura churches in the 1920s and 1930s emphasized the centrality of God's power and prayer to address all human problems. Moreover, in the 1960s in the Isoko area of Delta State, an evangelist, Adam Igbudu, led a group which was called Olezi (i.e. Holy Spirit). The Olezi partly inspired Michael Marioghae, a 1964 graduate of the University of Ibadan, who moved from the Anglican Church and established his church, the Holy Spirit Mission, in the 1980s in Benin City. This new church further indicates a continuing affinity to the power of the Holy Spirit. Overall, charismatic Christianity as a new religious phenomenon is still grounded in the pneumatic elements of African Christianity, and to some extent forms a continuity with existing strands of African Christianity.

Storms (2012:53) points out clearly that tongues, prophecy, and knowledge as special gifts will continue until the second coming, and bases this on an interpretation of 1 Corinthians 13:8, 9, which makes the word "perfect" refer to the second coming of Christ. It is obvious that in the view of the tongues-speakers, this gift of tongues is to persist until the return of Christ, and that all believers must receive the baptism in the Spirit in this day with 
its attendant evidence of tongues or be sadly deficient in many graces. Still on Speaking in Tongues, is the initial evidence of having been baptized in the Holy Spirit. In the Saturday Evening Post (6 May 1964) McCandlish claims that some tongues-speakers have claimed that modern "tongues" are intelligible foreign languages they have never studied which can be both known and unknown (McCandlish 1964). The tongues on the day of Pentecost were unknown to the Apostles (Acts2:7) but were known by many that heard (Acts 2:8). This is sometimes the case today. The Spirit therefore chooses the language, and while most seem to be the languages of men, i.e., languages that have been or are spoken by men, it can also be a heavenly or angelic language (1 Cor 13:1). Acts 2:6 also adds that there is descriptive evidence that speaking in tongues was a known foreign language, as everyone heard the gospel in their language.

There are three words in Greek for "tongues" in the Bible, but the primary word for tongues in Acts is $\Gamma \lambda \tilde{\omega} \sigma \sigma \alpha$ ("Glossa") (a noun feminine plural dative) is found in Acts 2:4, 11; 10:46; 19:6), when "tongues of fire" appeared above the apostles' heads. It also refers to the tongue as a speech organ and the supernatural gift of speaking in another language without it having been learned. The second Greek word used in the Bible is $\delta$ เá $\lambda \varepsilon \kappa \tau o \varsigma$ ("Dialektos") (a feminine noun in the dative case and singular form) refers to another language or dialect on two occasions found in Acts 2:6,

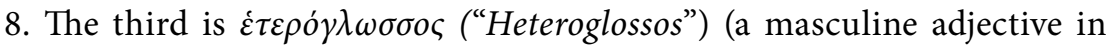
the dative case and plural form) refers to "other tongues" and is used in 1 Corinthians 14:21. All these three Greek words are indicative of a native, existing language of mankind. It is interesting to note, despite the Greek's detail when words have different meanings as seen in the word "love", it is the same root meaning used every time in the New Testament when "speaking in tongues" is referenced. The Bible is silently providing no hint of existence regarding "ecstatic utterances" or a "heavenly prayer language" by definition.

In the light of the Pattison position, one can infer that there are three possible sources of glossolalia. First, this experience could be self-induced. The power of peer-pressure from other Christians can indeed be strong. Psychological factors play a role. A person's strong desire for spiritual experiences can bring about a false experience that seems very spiritual, aided by false teaching about the gift of tongues, many are confused in their 
genuine search for truth. A second possible source of glossolalia is demonic influence. Our historical study demonstrates this as displayed in the many pagan cults that practiced glossolalia. Satan transforms himself into an angel of light and thus can deceive people with false teaching and false experiences (2 Cor11:14). The scripture is clear that we should test all things (I Thess 5:21, I Cor 14:29, I John 4:1-3). Finally, glossolalia can be sourced in God. In this case, it would be a known human language supernaturally endowed by God for His purpose, and according to the scriptural pattern (Pattison 1964:99).

\section{The use of speaking in tongues in the Scripture and our contemporary time}

Abashiya (2012:2-6) also agrees with the scripture that, Jesus was crucified at Passover time, and he ascended 40 days after his resurrection. The Holy Spirit in the Tongues of fire came upon men exactly fifty days after Jesus' resurrection, ten days after the ascension. In other words, Jesus was with them for forty days and the grace came upon them ten days after. Thus, Peter's speech (Acts 2:14ff) was given to an international audience, and it resulted in a worldwide harvest of new believers - the first converts to Christianity. From that time onward, every release of God's spirit upon believers in the Acts of the Apostles always has their first manifestation of speaking in tongues as was also the experience of Cornelius, a gentile but devoted convert (Acts 10:44-46).

Below are some of the uses of tongues: First, in Acts 2:11: ("We hear them declaring the wonders of God in our own tongues".) This is an indication that tongues were used to communicate the Good News to expatriate Jews of other language groups. The book of First Corinthians (which contains the major teaching on tongues) was written to a church located in Corinth. The Christians there had much exposure to people of various language groups, due to the international shipping that passed by the canal, through the Isthmus of Corinth. The value of tongues-speaking for corporate worship and preaching would be obvious in the light of the sailors and travellers frequenting that city. Hasel (1991:32) also argues that if speaking in tongues does not serve to communicate, how can it benefit the church? 
Speaking in tongues is for the benefit of the church; it is not for the benefit of the person who is the tongues-speaker alone.

Second, tongues were given for a sign of judgment. Isaiah the prophet warned the Old Testament Jews that God would bring judgment on Israel using a people who spoke a foreign language. Isaiah 28:11 says, "Very well then, with foreign lips and strange tongues God will speak to this people." In context, this evidence would be the Assyrians. Israel was aghast at the thought that God (being infinitely holy) could or would use gentiles to discipline Israel. Since Israel wouldn't discipline herself, the foreign speech was a sign of God's judgment. Assyria did come and defeat Israel and take them away into captivity. In Acts 2 on the day of Pentecost, tongues, besides being a communication tool, was a sign of God's judgment on the nation Israel. Because Israel rejected Jesus as her Messiah, God was now offering the Good News to people of other language groups. As outlined in Acts, the gospel was soon to escape the birthing place of Jerusalem and Israel and go out to the Samaritans and even the whole world.

But you will receive power when the Holy Spirit comes on you, and you will be my witnesses in Jerusalem, and in all Judea and Samaria, and to the ends of the earth (Acts 1:8).

Instead of God using the Jews, He was reaching past them to begin working through the gentiles, using "non-Jewish" languages - all because Israel rebelled against God (see Romans 10-11). Historically, we see that God, began to use the Gentiles (i.e. Christians) as a means of bringing Israel back to himself (see Romans 11:30-31). Tongues at Pentecost was a subtle judgment on Israel that they no longer were God's primary instrument in reaching the nations. The Apostle Paul quotes that passage from Isaiah (see above) and applies it to the Corinthian context.

In the Law it is written: "Through men of strange tongues and through the lips of foreigners I will speak to this people, but even then they will not listen to me," says the Lord. Tongues, then, are a sign, not for believers but for unbelievers ...(1 Corinthians 14:21-22).

Tongues speaking would be a sign to unbelieving Jews (in Corinth and everywhere) of coming judgment for unbelieving Jews (in the same way as the foreign speech was a sign to the unbelieving Jews in Isaiah's time). 
The fact that tongues were evident among the Corinthian believers would doubtlessly remind the Jewish community in Corinth that God was now working with Gentiles (other language groups) - once again a sign of judgment on Israel.

Grudem (2011:12), Chester (2005:444-445), and a host of other scholars explicate tongue-speaking, originally as a sign of judgment to the Jews as now applied to the Gentiles. Arndt and Gingrich (1957:112) accurately interpret hai glossai eis semeion when they say, "' It does not say that tongues are a sign,' but that they are 'for a sign.' This means that tongues are intended to serve the purpose of a sign." The tongues-sign, therefore, was the final divine. Isaiah the prophet warned the Old Testament Jews that God would bring judgment on Israel using a people who spoke a foreign language. Isaiah 28:11 says, "Very well then, with foreign lips and strange tongues God will speak to this people." In context, this evidence would be the Assyrians. Israel was aghast at the thought that God being infinitely holy could or would use gentiles to discipline Israel. Since Israel would not discipline herself, foreign speech was a sign of God's judgment. Assyria did come and defeated Israel and took them away into captivity in 732 BC (Unger 1984:246).

Third, tongues were given for the edification of the church. As with all spiritual gifts, tongues were not given for an individual's (i.e. the tongues speaker) own benefit.

"Now to each one the manifestation of the Spirit is given for the common good" (1 Cor 12:7). These are body life gifts to be used for building up the body of believers. The purpose was not to bless or edify the individual who possessed the gift. The Holy Spirit through the Apostle Paul addresses this concern and explains that self-edification was precisely what was wrong with the Corinthian abuse of tongues!

For anyone who speaks in a tongue does not speak to men but to God. Indeed, no one understands him; he utters mysteries with his spirit ... He who speaks in a tongue edifies himself, but he who prophesies edifies the church (1 Cor 14:2, 4).

As Joseph Dillow (1975:78-79) points out, “... referring to 1 Corinthians 14:4 does not help us in the discussion of the purpose of the gift, because 
what this passage describes is an accompanying product of the exercise of the gift. Any man is edified as he exercises his gift. But we can't say, for example, that because the man who has the gift of evangelism is edified as he evangelizes, the purpose of the gift of evangelism is personal edification. When Paul says that "... he who speaks in a tongue edifies himself”, he isn't commending the Corinthians for their spirituality! He is rebuking them for their misuse of the gift. As a spiritual gift, tongues have the purpose of edifying the Church (1 Cor 12:7; 14:12). For this to happen in a church meeting, they must be manifested by no more than three speakers and must be interpreted.

If anyone speaks in a tongue, two - or at the most three should speak, one at a time and someone must interpret. If there is no interpreter, the speaker should keep quiet in the church and speak to himself and God (14:27-28).

This mandate provides for both the foreign audience who can understand the foreign language spoken as well as the local audience.

Fourth, tongues, as one of the sign gifts, served to authenticate the ministry of the early Christians, particularly the Apostles, and the spread of the Word of God.

The signs of a true Apostle were performed among you with all perseverance, by signs and wonders and miracles (2 Cor 12:12). God also bearing witness with them [i.e. the apostles], both by signs and wonders and various miracles and by gifts of the Holy Spirit according to His own will (Hebrews 2:4).

In today's Christian scenario in Nigeria, it is almost impossible to imagine an authentic minister of God devoid of spiritual gifts. Charismatic spirituality in Nigerian mainline churches is better described as an appraisal of an indepth religious consciousness, or as an un-concealment of the divine and an in-breaking of the fundamental religious expectations among the people. According to Hocken ((2001:82), "In Nigeria, all the denominations are experiencing renewal. Prayer and fasting and signs and wonders of healing and deliverance are common." This observation indicates the impact of Pentecostalism on the mainline churches in Nigeria. The explosion of Pentecostalism introduced into Nigeria a spirituality that was not fostered 
by the initial western missionaries. It inaugurated an approach to faith and ecclesial polity that is glaringly different from the initial practices of the mainline churches. Pentecostalism has awakened a tremendous yearning for a primal spirituality in the country.

Olupona (2000:xxiv) states that the presence and the realness of the divine power are intrinsic to the African worldview. The question of the cessation of charism and miracles, the divine that will not intervene in the living situation and everydayness of the people was only a bitter theological pill that many Africans were advised to swallow but only to hang at their throats. The outburst of charismatic experience in the historic churches of the West and its diffusion to Africa was seen as the divine way of proofing the western theology of mechanistic world, where God is a hidden and silent observer, to be existential unbelief of some western missionaries. Therefore, charismatic experiences in the mainline churches in Nigeria as "manifestation of spiritual gifts and evident power of the Holy Spirit are being lived and seen as normal Christian life and not as the expression of a particular movement."

In an interaction with Pastor Ajala, the researcher was made to know that, in the Indigenous churches like Christ Apostolic Church, speaking in tongues is often used during prayers, worship to relate messages to the church. More often than not, the speaker speaks the language of the target audience which may be in the form of warning, instruction, or rebuke (Ajala 2019). In an interview with Pastor Idowu (2019) he affirms that in the Apostolic Church, the first Sunday of the month is considered as the Pentecostal Sunday in which members would be called out. Both elders and deaconesses would surround the rest of the members, especially youth. The pastor calls upon the members to ask for Holy Spirit baptism, suddenly some of them would start speaking in tongues which usually leads to prophecy, divine messages that lead to healing, warning, or rebuke for those who have done something wrong. During revival time, the church enjoys this more. In Cherubim and Seraphim, Pastor Ajayi agrees that it is a bit different, the interpreter then interprets the message which can be a means of exposing the craftiness of the devil, warning for those who are committing secret $\sin (\mathrm{s})$ in the congregation (Ajayi 2019). In the opinion of Ogunewu (2009:24) the glossolalia practiced in Paul's churches was unintelligible speech, uttered to God. For example, Mr. Adeniji, in an interview confirms 
the fact that Pastor Dr. D.K. Olukoya, the founder of Mountain of Fire Miracle Church, would first speak in tongues, then prophetic declaration would follow with signs and wonders as living evidence. Apostle Johnson Suleman, the founder of Omega Fire Ministry, in the course of his ministration he speaks in tongues, from there he makes divine revelations known to the congregation and is also followed by outstanding miracles. Dr. Paul Eneche, the founder of Dunamis International Gospel Centre, as he preaches speaks in tongues which is also followed by a prophetic declaration that leads to miracles (Adeniji 2019). The researcher also agreed with Zodhiates (1997:175) who states that conservative evangelicals generally argue that the primary purpose of glossolalia was evangelistic since the reason for any biblical gift is to save souls.

According to Reese (1999:102), as we compare the accounts in Acts 2 and 1 Corinthians 12-14, we see that in both the Corinthian and Pentecostal cases, an extraordinary influence and gift of the Holy Spirit was responsible for the speaking. In both cases, the people were speaking as the Spirit led them to speak. The intention of speaking in tongues in both cases was to bring praise and honour to God and to edify the hearers. In the opinion of Fee, 1 Corinthians, which contains the major teaching on tongues, was written to a church located in Corinth, a major port city. The Christians there had much exposure to people of various language groups, due to the international shipping that passed, by the canal, through the Isthmus of Corinth. The phenomenon would be used for corporate worship and preaching would be obvious in the light of the sailors and travellers frequenting that city (Fee 1987:656;

Tongues have been used as an acid test, a sign to further authenticate the reality of the word of God. Pastor Ajala (2019) he submits that in CAC either during normal service or revival time, God has used tongues to reestablish His word and to further develop the faith of church members too. Pastor E.A Adeboye is accustomed to speaking in unknown tongues while he is in Spirit; however, he gives an adequate interpretation thereafter. This signifies that he recognizes the importance of interpreting tongues, to avoid confusion in the church. Pastor Adedeji noted that he exhibits this character only when the need arises, by how the Holy Spirit leads him (Adedeji 2016). 
MacArthur further stressed strongly the significance of speaking in tongues for personal prayer life and found in it a source of spiritual refreshment, but he refused to accept that speaking in tongues is the only sign of the baptism in the Holy Spirit. "For me - the gift of tongues turned out to be the gift of praise. As I used the unknown language which God had given me, I felt rising in me the love, the awe, the adoration, pure and incontinent, that I had not been able to achieve in thought and prayer" (MacArthur 1978:21). Still, on prayer, Early Pentecostals found this time that these tongues serve as a useful way to praise and worship God, as a prayer language (Anderson 1979:89; McGee 2007:1; Synan 1997:89).

Furthermore, in the employment of "tongues," one often enters into the realm of poetry and music. In the words of Pastor Bamidele, this is common with so many Pentecostal and Indigenous churches. Apostle John Suleman, the founder of Omega Fire Ministry, Dr. Paul Eneche, the founder of Dunamis International Gospel Centre, Bishop David Olaniyi Oyedepo, the founder of Living Faith Church, Prophet Korode of Cherubim and Seraphim Church, Ilorin among others, often sing in tongues while ministering deliverance to the congregation (Bamidele 2019). Matthew Ashimolowo is a Nigerian clergyman, the Senior Pastor of Kingsway International Christian Centre in London also signs in tongues Pastor Adeyemi also adds (2019).

Speaking in tongues encourages church members to express their emotions rather than suppress them. With the numbers of years in the ministry and as a lecturer in one of the seminaries in Nigeria, researcher have discovered over time that the Pentecostal and indigenous churches are the fastestgrowing segments of Christianity, especially in Nigeria. One of the likely reasons they are growing is that they encourage people to express their emotions rather than suppress them. This can be bad if people's faith is built on emotions, but it is good if those emotions are a genuine response to the good news of Jesus Christ. Pentecostal and indigenous churches are generally freer in how they express this joy. Visitors who attend a Pentecostal or an indigenous church are likely to see people expressing joy and happiness because of their faith in Jesus Christ. This example is an effective aid in evangelism and church growth. This unusual event at Cornelius' house was proof that God had opened the door of salvation to the Gentile world. They spoke in other languages, before being baptized 
into Christ. The Holy Spirit had manifested Himself by the fact that He "came upon them." This was an "outside" manifestation, not an "inside" dwelling. Surely God was opening salvation's door to all of mankind, not just to the Jews. These Gentile believers were immediately baptized into Christ. Peter refers to these believers receiving the Holy Spirit "just as we have." He is referring to the Spirit's gift of speaking in tongues which happened on the day of Pentecost (Acts 10:44-46).

\section{The abuse of tongues}

There are eight prominent wrong notions about speaking in tongues that have been observed in some Christians and churches where speaking in tongues is not encouraged which needs to be examined. According to Reed (2018) the first wrong notion is that speaking in tongues is gibberish and meaningless. The second is that speaking in tongues is meant solely for the Christian speaker's private use and can only be used in any public Christian gathering when it is interpreted. The third is that speaking in tongues must be forbidden in the church when there is no interpretation. The fourth is that Paul prefers prophecy to speak in tongues because prophecy edifies the entire church. The fifth is that the early church's speaking in tongues must always be initiated by the Holy Spirit. The seventh is that the gift of speaking in tongues is not for today's Christians. And lastly, speaking in tongues makes the Christian speakers more spiritual than those who do not speak in tongues. Apart from wrong notions about this phenomenon, here are some of the ways it has been abused over the years.

1. It is abuse when spiritual gifts are used as a means of manipulation, power, or control in personal and/or church relationships (1 Cor12:4-6). When God is working, and the Lord Jesus is exalted, and the Spirit of God is bestowing gifts and operating in the body of Christ, it's for the common good. It builds people up. The focus is on the Godhead, not on the gifts. The focus is on what God is doing in the group, not on people's particular passions, or bents. Personal control, manipulation, and use by gifts are always a sign that abuse is occurring. It is abused in the Orthodox and Evangelical Churches when used during prayer and cooperates worship to intimidate, terrorize and impress others through unnecessary shout. Some of our postgraduate students in the University of Ilorin who are senior 
pastors and priests told the researcher that they also believe it and even some of them speak in tongues but privately. Their position is that since there is no interpreter it should not be encouraged (Femi-Olubiyi 2019).

2.It is abuse when anyone claims to have the ability to give, or bestow, any particular gift if you follow their formula. Notice what it says in I Corinthians 12:11, "All these gifts are of the same Spirit, and He gives to each one just as He determines." Paul speaks of the spiritual gifts. He says, "God gives, or bestows gifts," literally, it's, "as he wills." The Greek word is a very interesting one. It means "as He chooses, after careful deliberation". Ephesians 2:10 says, "We are his workmanship, created in Christ Jesus unto good works, which God has before ordained that we should walk in them." And so, when someone comes up and says, he has the power to distribute the gifts," he is taking the role of the Holy Spirit. It is, therefore, an abuse whenever anyone claims to have the ability to give, or bestow, any particular gift if you follow their formula.

3. It is considered as an abuse of tongues when any particular gift is made universal evidence of spirituality, salvation, or other spiritual blessings. 1Corinthians 12:29-30 asks a rhetorical question: "Are all apostles?" No. "Are all prophets?” No. "Are all teachers?” No. "Do all work miracles?” No. "Do all have gifts of healing?" No. "Do all speak in tongues?" No. "Do all interpret?" And he's making the point, in I Corinthians 12:29-30, that no one has all the gifts. It means that no one has all the gifts. It's a rhetorical question, and the answer is no. Therefore, is an abuse of tongues for any church to teach such.

4. When the focus of a church service ministry or religious event is on spiritual gifts and their manifestation, rather than on the giver of the gifts, and his agenda for the church it is an abuse. This is where you hear about "the miracle service," "So-and-so is going to happen" as advertised. It is a misplacement of priority. That is why we have a lot of movement of members instead of real converts. People are after miracles rather than the salvation of their souls. This, in turn, has led to simony. In Ephesians 4:11-12, Paul says, "He gave some as apostles. He gave some as prophets. $\mathrm{He}$ gave some as evangelists. He gave some as pastors and teachers." Why? For the work of service to build up the body for the work of service. Spiritually gifted people are to equip us, regular believers and saints, so that we can do 
the work of service until every single Christian grows up into maturity, to all the measure of the fullness of Christ. He did not give spiritual gifts so that people could make a lot of money, put on a show, and tell people how awesome, miraculous, and wonderful their deal is?

5. It is abuse when you compare your gifts with anyone else's. It always leads to carnality. Do not compare your gifts. 1 Corinthians 12:11, "All these are the work of the same Spirit. And he gives them" - the Spirit - "gifts to each one." How? "Just as He determines. The body is a unit." "Though it is made up of many parts, and though all its parts are many, they form one body" - given the human body - we have a hand. We have a head. We have eyes. We have ears. We have feet. "And so, it is with Christ. For we were all baptized by one Spirit into one body, whether Jew or Greeks, slave or free, and we were all given one Spirit to drink. Now the body is made up of not one part, but many." Paul goes through the analogy in verse 15 "If the foot should say, 'Because I'm not a hand, I don't belong to the body,' would it not for that reason cease to be any part of the body?" I mean, less? No. "And if the ear should say, 'Because I am not an eye, I don't belong to the body,' it would not for that reason cease to be a part of the body," would it? Well, no. "If the whole body were an eye, where would the sense of hearing be? And if the whole body were an ear, where would the sense of smell be? But in fact, God has arranged the parts in the body, every one of them, just as he wanted them to be." Don't compare your gift to someone else's. Though certain churches and certain individuals gravitate to honour certain gifts more than other gifts, Pastor (Mrs) Femi-Olubiyi identifies such as Prophet Sanmi Metiboba of Seed of Faith ministry Flamingo close, Ilorin, the same is parading himself as the major prophet of our time now. Some other prophets like Olubo, Jayeoba among others in Ilorin alone, advertise their spiritual gifts for patronage (Femi-Olubiyi, 2019).

\section{Conclusion}

Glossolalia is not unique to Christianity. We have seen that the mere existence of it does not prove it is from God in every case or in any case. This experience, whatever it is, is found historically where it is not related to occur before, during, and after the time of the NT, though it faded out shortly during the first century until isolated occurrences happened around 
the 1300's. Most records up to the 1900's concern fringe groups or are poorly substantiated. Other doctrines or practices involved in these groups were questionable. It is only in the second half of the 20th century that there has been a widespread resurgence of "tongues." This phenomenon has caused serious problems in the church today as a result of its misuse. Students have been expelled from Bible colleges over the issue. Preachers have been asked to resign from pulpits because of "speaking in tongues". Reports of the gift of tongues in some miraculous form have existed at different times; but, as with reports of miraculous healing, they are generally difficult to verify because there are counterfeits, especially in the last days. However, the church must, therefore, be opened and sensitive to this manifestation, because it can only manifest where it is celebrated and not just tolerated. The paper submits that despite all the seeming benefits which people are probably deriving from this phenomenon, preachers should note that people's eternal destinies are to be pursued far above people's immediate manifestation of speaking in tongues which in return can bring material gains here on earth.

\section{References}

Abashiya, C.S. 2012. Tongues: To Speak or Not to Speak. Jos: Challenge Press.

Achunike, H.C. 2004. The Influence of Pentecostalism on Catholic Priests and Seminarians in Nigeria. Africana First Publishers Limited.

Adedeji, E. 2016. Interview with the pastor of the Redeemed Christian Church Of God, Agbo-Oba, Ilorin.

Adeniji, T.A. 2019. Interview with graduate of FUTA, Akure.

Adeyemi, L. 2019. Interview with the professor of the Department of Linguistic University of Ilorin.

Ajala, S.A. 2019. Interview with the pastor of the Christ Apostolic Church, Oke Aanu, Surulere Headquarters, Sawmill, Ilorin.

Ajayi, S. 2019. Interview with the pastor of the Cherubim and Seraphim Church, Ipetumodu,Osun State. 
Anderson, Allan 2004. An Introduction to Pentecostalism. Cambridge: Cambridge University Press.

Arndt, W.F. 1979. "Г $\lambda \tilde{\omega} \sigma \sigma \alpha$ ” in a Greek English Lexicon of the New Testament and Other Early Christian Literatures. London: University of Chicago Press.

Bamidele, A. 2019. Interview with the pastor of the Winners Chapel Church,Gaa-Imam Parish.

Brumback, C. 1947. What Meaneth This? Springfield: The Gospel Publishing House.

Cartledge, M.J. 2006. Speaking in Tongues: Multi-Disciplinary Perspectives. Milton Keynes: Paternoster.

Chester, S.J. 2005. "Divine madness? Speaking in tongues in 1 Corinthians 14.23." Journal for the Study of the New Testament, 444-445.

Dalton, R.C. 1945. Tongues Like as of Fire. Springfield, Mo: The Gospel Publishing House.

Dillow, Joseph 1975. Speaking in Tongues: Seven Crucial Questions. Grand Rapids: Zondervan Publishers, 1975.

Fee, G. 1987. The first Epistle to the Corinthians: New International Commentary on the New Testament. Grand Rapids: Eerdmans.

Femi-Olubiyi, E.A. 2019. Interview with a ECWA Pastor's Wife, ECWA Yoruba Session, Yelwa-Yauri, Kebbi State.

Grudem, W. 2011. Making Sense of the church. Grand Rapids: Zondervan.

Hasel, G.F. 1991. Speaking in Tongues: Biblical Speaking in Tongues and Contemporary Glossolalia. Adventist Theological Society Monographs 1. Berrien Springs, MI: Adventist Theological Society.

Hocken, P.D. 2001. Charismatic Movement. In New International Dictionary of Pentecostal and Charismatic Movements, 510-511.

Horton, H. 2007. The Gifts of the Spirit. Great Britain: Zondervan. 
Idowu, O. 2019. Interview with the pastor of the Apostolic Church, Akata, Ilorin.

Isichei, E. 1995. A History of Christianity in Africa from Antiquity to the Present. Grand Rapids, Micigan: Eerdmans.

Klaude, K. 1961. The Promise Fulfilled: A History of the Modern Pentecostal Movement. Springfield: Gospel Publishing House.

MacArthur, J. 1978. The Charismatics: A Doctrinal Perspective. Zondervan: Zondervan Publishing House.

McCandlish, P. 1964. And There Appeared Unto Them Tongues of Fire. Saturday Evening Post.

McGee, G. 2007. 'Brought into the sphere of the supernatural: How speaking in tongues empowered early Pentecostals. Encounter, 1-16.

Menzies, G. 1998. Tongues as “The Initial Physical Sign” of Spirit Baptism in the Thought of D.W. Kerr. Pneuma, 175-187.

Ogunewu, M.L. 2009. Dictionary of African Christian Biography. Ibadan: Covenant Publisher.

Ojo, M.A. 2018. "Pentecostalism and Charismatic Movements in Nigeria: Factors of Growth and Inherent Challenges." WATS Journal: An Online Journal from West Africa Theological Seminary, September 2018, 3(1):74-94.

Olupona, J.K. (ed.) 2000. African Spirituality: Forms, Meanings and Expressions. New York: The Crossroad Publishing House.

Pattison, M. 1964. Speaking in Tongues and about Tongues. Christian Standard.

Procter. P. 1981. "Multilingual" in Longman Dictionary of Contemporary English 5th ed. England: Longman Publishing House. 717.

Reed, M. P. 2018. How can speaking in tongues be abused. [Online]. Available: https://books.google.com.ng. [Accessed: 26 January 2018].

Reese, G. 1991. New Testament History: A Critical and Exegetical Commentary on the Book of Acts. Joplin, MO: College Press. 
Storms, S. 2012. The Beginner's Guide to Spiritual Gifts. Regal: Ventura.

Synan, V. 1997. The Holiness-Pentecostal Tradition: Charismatic movements in the twentieth century, 2nd edition. Grand Rapids: Eerdmans.

Unger, M.F. 1984. The New Unger's Bible Handbook. Chicago: Moody Press.

Verbrugge, V.D. 2000. $\gamma \lambda \tilde{\omega} \sigma \sigma \alpha$ in New International Dictionary of New Testament abridged edition. Grand Rapids: Zondervan.

Zimmerman, T.F. 1963. "Pleas for Pentecostalists." Christianity Today, (4):11-18.

Zodhiates, S. 1997. Speaking in Tongues and Public Worship: An Exegetical Commentary on First Corinthians Fourteen. Chattanooga: AMG. 
